\title{
Hermeneutika Hadis: \\ Tinjauan Pemikiran Yusuf Al-Qordhowi dalam Memahami Hadis
}

\author{
Siti Fahimah \\ Institut Agama Islam Tarbiyatut Thalabah Kranji \\ fahimahsiti@gmail.com
}

\begin{abstract}
Hadith as the Qur'an is a text produced from the past and destined for all time, past and present. In understanding the products of the past many methods for its understanding can be catered for the benefit of the people. Hermeneutics is present as a new method for understanding past product texts in order to be applied to the present, in the heremenutics are three kinds, those are texts, contexts and authors can unite to produce a 'similar' understanding to what the text writer intended Allah (al-Qur'an) or Prophet Muhammad (Hadith). In understanding the text of the Qur'an has been offered an understanding by using methods of heremeneutic with clear steps, as well as Hadith, many ways of understanding hadith, among whichwas put forward by Yusuf Qordhowi, he emphasized the understanding of hadith on maqashidmas-syariah and pay attention to asbab alwurud hadith and try to find its contextual significance. In an attempt to understand the hadith, Al-Qordhowi mindset has been constructed in such a way that he in understanding the hadith always concerns the internal of the hadith without forgetting to use the external approach. Where the intersection between the goal of understanding hermeneutics with the study of Yusuf Qordhowi's Hadith.
\end{abstract}

Keywords: Hermeneutics, Hadith, understand hadith and Yusuf al-Qordhowi

Abstrak: Hadis sebagaimana al-Quran adalah teks yang dihasilkan dari masa lalu dandiperuntukkan untuk sepanjang masa, masa lalu dan juga masa kini. Dalam memahami produk masa lalu banyak metode agar pemahamannya bisa diperuntukkan demi kemaslahatan umat. Hermeneutika hadir sebagai metode baru untuk memahami teks produk masa lalu agar bisa diaplikasikan pada masa kini, didalam heremenutika dikenal yang nama nya tringual, yaitu bagaimana teks, konteks dan pengarang bisa bersatu untuk menghasilkan sebuah pemahaman yang 'mirip' dengan yang dimaksudkan oleh sang pembuat teks yaitu Allah(alquran) atau Nabi Muhammad (Hadis). Dalam memahami teks alquran sudah ditawarkan pemahaman dengan menggunakan metode heremeneutika dengan langkah-langkahyang jelas, begitu juga dengan Hadis, banyak cara dalam memahami hadis, diantaranya yang dikemukakan oleh Yusuf Qordhowi, beliau 
lebih menekankan pemahamana hadis pada maqashid as-syariah dan memperhatikan asbab wurud hadis serta berusaha menemukan signifikansi kontekstualnya. Dalam upaya memahami hadis, pola fikir al-Qordhowi telah terkonstruksi sedemikian rupa, sehingga beliau dalam memahami hadis selalu memperhatikan sisi internal dari hadis dengan tidak melupakan menggunakan pendekatan eksternal. Disinilah titik temu antara tujuan pemahaman hermeneutika dengan pehamahan hadis ala Yusuf Qordhowi.

Kata kunci: Hermeneutika, hadis, memahami hadis dan Yusuf al-Qordhowi

\section{Pendahuluan}

Hadis sebagai sumber kedua setelah alquran memiliki kedudukan yang sama penting, karena alquran tidak bisa berdiri sendiri melainkan memerlukan hadis dalam memahami makna teksnya. Tetapi ada problem mendasar yang agaknya pengkajian terhadap hadis menjadi sangat urgen. Pertama, munculnya problem-problem baru yang sangat banyak, padahal belum ada penjelasan jelas dari syari'. Kedua, pendekatan konvensional yang selama ini dipakai agaknya kurang lagi bisa menjawab persoalan yang terus bermunculan pada era modern saat ini. Ketiga, adanya pemikiran baru yang muncul dan memberikan alternatif yang perlu disosialisasikan dan dikritisi. ${ }^{1}$

Sementara kajian kontemporer saat ini agak 'menelantarkan' metode pemahaman hadis dalam masalah dan isu-isu aktual, seolah hadis terlupakan atau menjadi suatu yang tersisa. Sedangkan banyak ulama dan cendekiawan muslim mengkaji dan menafsirkan alQuran dengan menawarkan beberapa metode baru dalam upaya mengeksplorasi ayat-ayat al-Quran, tetapi tidak terhadap hadis. ${ }^{2} \mathrm{Hal}$ ini itu bisa dikarenakan adanya kekhawatiran atas label 'ingkar assunnah'. Oleh karena itu, tidak heran bahwa upaya pemahaman hadis tertinggal jauh dari penafsiran alquran, bahkan kebanyakan ulama mendahulukan sikap hati-hati (reserve) untuk menelaah ulang dalam pengembangan pemikiran agar tidak terjadi ketimpangan yang luas dan juga sebagai upaya untuk mempermudah dalam kegiatan pehamaman hadis secasar bebas tetapi terkendali.

Persoalan itu muncul karena hadis tidak mempunyai kekuatan setingkat alquran yang qath'iy dan mendapat jaminan dari Allah, sementara kualitas hadis hanya sebatas dhonny, ${ }^{3}$ dimana kebenarannya masih perlu penelitian, sehingga ulama tersibukkan dengan membeda akan nilai hadis tersebut dari sisi sanadnya, sehingga hadis yang bisa dikupas dengan menggunakan metode yang baru 
haruslah hadis shohih, ${ }^{4}$ sehingga akan didapatkan pemahaman yang mendalam dan bisa dipakai untuk diterapan, karena hadis juga bukan terlahir sebagai teks mati, melainkan menjadi sunnah yang senantiasa hidup, hal ini tidak bisa hanya menggunakan pendekatan konvensional saja melainkan harus mau dan mampu memakai metodologi baru.

Urgensi hadirnya metodologi baru yang sistematis untuk pemaknaan hadis semakin jelas ketika kita hendak berupaya melakukan perumusan kembali atas maksud dari suatu hadis yang sesuai dengan dinamika masyarakat dan mampu menyerap perubahan-perubahan, baik yang spasial, temporal, maupun yang universal sehingga maksud dari hadis mampu menyentuh rasa keadilan dan tidak terjadi 'bias'. ${ }^{5}$ hal itu dilakukan agar hadis bisa difahami dan disesuaikan antara teks dan konteks yang ada.

Lontaran-lontaran tentang prinsip-prinsip pemaknaan hadis yang sistematis dan baru sudah banyak dilakukan oleh tokoh-tokoh Islam, diantaranya Muhammad Iqbal, dalam karyanya The Reconstruction of Religions Thought in Islam, ${ }^{6}$ berpendapat bahwa orang yang akan mengambil pelajaran dari hadis harus membedakan antara hadis yang membawa konsekwensi hukum atau tidak, harus meneliti sejarah bangsa arab sebagai penerima awal hadis dan pada kondisi apa hadis itu diucapkan. Sama halnya dengan Iqbal, adalah Yusuf Qordhowi yang berusaha memahami hadis secara konseptual dan sistematis. Baliau menulis dalam kajiannya tentang pemahaman hadis dalam bukunya yang berjudul 'kaifa Nata'amal Ma'a as-Sunnah an-Nabawiyah. Dalam buku itu, beliau menganjurkan beberapa prinsip penafsiran hadis yang proporsional yaitu tidak hanya secara tekstual nya saja tetapi juga secara kontekstual dan memperhatikan kondisi hadis atau disebut historis dan sosiologis hadis, sehingga pergesaran makna hadis akan muncul seiring dengan perubahan zaman. $^{7}$

Dalam perkembangannya, buku tersebut menjadi acuan para pemerhati dalam kajian hadis, selain hanya karena pada awalnya buku tersebut adalah hasil dari perdebatan antara beliau dengan alGhozali tentang cara memahami hadis yang benar agar tidak dituduh ingkar sunnah, tetapi juga karena Yusuf Qordhowi adalah ulama yang dianggap sebagai ulama yang demokrtaris, tidak liberal, tetapi juga tidak ekstrim dan tidak teks oriented tetapi lebih mementingkan pada maqashid as-syariah. Salah satu pemahaman al-Qordhowi adalah anggapan penting adanya asbab al-wurud, dengan adanya teori asbab alwurud mengisyaratkan bahwa ada akar-akar historis dalam kajian hadis mengenai pemahaman secara hermeneutis. 
Metode-metode al-Qordhowi itulah yang menjadi latar belakang penulisan artikel ini dengan mengkaji lebih jauh bagaimana pehamahan hadis alQordhowi dan ditinjau dari segi hermeneutika.

\section{Metode Penelitian}

Penelitian ini sepenuhmya merupakan penelitian kepustakaan (Library Reseach), oleh karena itu seluruh sumber yang digunakan didalamnya berupa sumber kepustakaan baik primer maupun skunder, sumber primer adalah bukubuku Yusuf Qordhowi yang membahas hadis, sedangkan sumber skunder adalah berupa buku-buku yang berkaita dengan hadis dan hermeneutika.

Selain itu, penelitian juga menggunakan cara deskriptif-analitis. Metode Deskriptif bertujuan untuk mendeskripsikan landasan teori yaitu yang berhubungan dengan metode pemahaman hadis, teori hermeneutika, pemahaman Yusuf al-Qordhowi dalam memahami hadis, sementara metode analitis untuk menganalisa kecocokan antara pehamahan al-Qordhowi dalam memahamii hadis dan teoriteori hermenutika yang ada dengan mengambil teori salah-satu tokoh hermeneutis.

\section{Pembahasan}

\section{Pemahaman Hadis}

\section{Pemaknaan Hadis pada Masa Awal}

Hadis $^{8}$ dalam arti perbuatan yang dilakukan Nabi SAW pada umumnya diterima berdasarkan riwayat dengan makna yaitu sebuah periwayatan yang tidak sama persis dengan apa yang diucapkan Nabi, dalam tataran teori periwayatan bil makna boleh dilakukan dengan persyaratan yang harus dipenuhi para perawi hadis. Sehingga pemahaman atas teks hadis yang dibawa sang perowi akan difahami sebagaimana penerimaan dan konteks waktu penerimaannya.

Dalam memahami sebuah teks hadis ada perbedaan pendapat, apakah pemahaman hadis harus dikaitkan dengan konteksnya atau tidak? Apakah konteks tersebut berkaitan dengan pribadi pengucapnya saja atau mencakup pula mitra bicara dan kondisi sosial ketika hadis diucapkan. ${ }^{9}$ Sementara di sisi lain, tipologi pemahaman ulama dan umat terhadap hadis diklasifikasikan menjadi dua bagian. Pertama, tekstual yakni tipologi pemahaman yang mempercayai hadis sebagai sumber kedua ajaran Islam tanpa mempedulikan proses panjag pengumpulan hadis, tetapi hanya memperhatikan lafalnya saja tidak memperhatikan aspek yang lain, seperti sejarah, atau makna yang tersembunyi di balik teks. Pemahaman tipe ini dikategorikan sebagai 
pemahaman yang ahistoris. Kedua adalah pemahaman kontekstual, yaitu pemahaman yang mempercayai hadis sebagai sumber kedua ajaran Islam dan melihat beberapa unsur dalam upaya pemahaman seperti melalui kritik-historis terhadap hadis hadis dengan melihat asbab al-wurud nya ${ }^{10}$ atau makna yang tersembunyi di balik teks.

Kondisi pemahaman yang tekstual dan kontekstula sudah pernah terjadi pada zaman Nabi ketika memahami hadis tentang pelaksanaan sholat ashar pada waktunya. Hadis tersebut diriwayatkan oleh Bukhori Muslim sebagai berikut: ${ }^{11}$

$$
\begin{aligned}
& \text { حدثنا عبد الله بن محمد بن أسماء، قال: حدثنا جويرية، عن نافع، عن ابن عمر، قال: قال النبي صلى الله }
\end{aligned}
$$

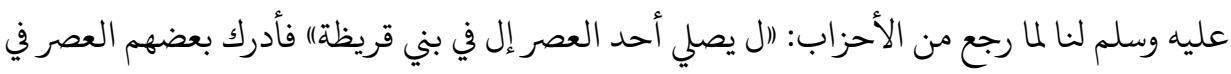

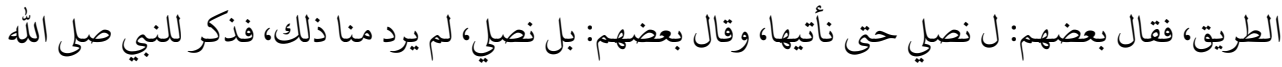

$$
\begin{aligned}
& \text { عليه وسلم، فلم يعنف واحدا منهم }
\end{aligned}
$$

Bercerita kepadaku Abdullah bin Muhammad bin Asma' dia berkata:bercerita kepada ku Juwairiyah dari Nafi' dari Ibnu Umar, dia berkata: Nabi SAW bersabda kepada kami ketika kami datang dari perang abzab: "janganlah seseorang di antara kalian sholat ashar, kecuali di perkampungan Quraidhoh" kemudian mereka mendapati waktu ashar di jalan. Sebagian mereka berkata: 'kita jangan sholat sebelum sampai di sana, sedangkan sebagian yang lain berkata: 'kita akan sholat ashar'. Kemudian mereka menceritakan kepada Nabi dan Nabi tidak menyalahkan keduanya"

Melihat teks hadis diatas, sahabat dalam memahami hadis Nabi ada perbedaan; pertama, ada yang memahami bahwa mereka harus sholat ashar di Bani Quraidhoh sehingga mereka harus bergegas sampai di tempat tujuan pada waktu masih ashar, mereka akan sholat ashar walaupun belum tiba ditempat tujuan, karena takut akan habisnya waktu ashar. Kedua, ada pula yang memahami bahwa perintah Nabi tersebut menekankan untuk sholat di Bani Quraidhoh, oleh karenanya mereka tidak melakukan sholat sebelum sampai tujuan walaupun waktunya ashar habis. ${ }^{12}$

Sementara Nabi menanggapi kasus kedua kelompok sahabat nya tersebut tidak menyalahkan keduanya, Nabi tetap mendiamkan perbedaan tersebut dan tidak memberikan komentar untuk membenarkan atau menyalahkan salah satu keduanya, dalam istilah hadis sikap Nabi ini disebut Hadis Taqriri. ${ }^{13}$ Menurut Jumhur Ulama bahwa kedua pemahaman tersebut adalah sama-sama benar, karena sahabat mencoba berijtihad dalam memahami hadis Nabi, seperti yang 
dikatakan as-Syafi'i bahwa setiap mujtahid ketika berijtihad itu benar maka mendapat pahala dua, jika salah mendapat pahal satu.

Melihat kasus di atas pada zaman Nabi sudah ada praktik pemahaman hadis yang tekstual dan kontekstual yaitu ada yang memahami apa adanya teks hadis, ada pula yang memahami dari apa maksud yang terkandung di balik hadis tersebut. Dalam kasus ini Nabi membolehkan pemahaman seperti itu.

Dalam kasus yang serupa, sahabat tidak mengamalkan apa yang dicontohkan Nabi karena melihat konteksnya yang berbeda, yaitu dalam kasus pembagian tanah bagi para pejuang. Pada masa Nabi membagi-bagikan tanah khoibar para pejuang, tetapi dalam kasus yang sama sahabt Umar tidak membagikan tanah rampasan perang di daerah Irak pada para pejuang. ${ }^{14}$

Dengan perselisihan pendapat tentang pemahaman ini menunjukkan bahwa kontekstualisasi pemahaman maknawi dan lafdzi sudah terjadi sejak zaman Nabi dan sahabat, sehingga hadis tidak harus dilihat secara teksnya saja, tetapi masih ada kemungkinan difahami dengan pendekatan yang lain yang tidak perlu ada ketakutan penuduhan bid'ah atau bahkan inkar as-sunnah, karena Nabi juga tidak mempersoalkan hal tersebut.

\section{Hermeneutika}

a. Pengertian Hermeneutika

Secara etimologi, kata hermeneutika adalah dari bahasa inggris yaitu hermeneutics yang asal katanya adalah bahasa Yunani hermeneuin artinya menginterpretasi, menjelaskan, menerjemahkan dan menafsirkan. ${ }^{15}$ Kata hermeneutika merupakan derivasi dari kata Hermes, seorang dewa dalam mitologi Yunani. ${ }^{16}$ Dalam konteks Islam, Hermes tak ubahnya seperti peran Nabi utusan Tuhan yang bertugas sebagai penerang dan penghubung untuk menyampaikan pesan dan ajaran Tuhan kepada Manusia. ${ }^{17}$ Bahkan Hossein Nashr berspekulasi bahwa Hermes tidak lain seperti Nabi Idris. ${ }^{18}$

Sedangkan secara terminologi, hermenutik diartikan sebagai penafsiran ungkapan-ungkapan dan anggapan dari orang lain, khususnya yang berbeda dari rentang sejarah. Bahkan dikalangan ilmuan klasik maupun modern telah sepakat bahwa hermenutika adalah proses mengubah sesuatu dari situasi ketidaktahuan menjadi mengerti ${ }^{19}$ dan mengeksplisitkan makna yang samar dengan bahasa yang lebih jelas, hermeneutik dapat juga diartikan dengan menerjemahkan dan bertindak sebagai penafsir. ${ }^{20}$ Dewasa ini hermeneutika sering dipersempit menjadi penafsiran teks tertulis yang berasal dari lingkungan sosial dan historis yang berbeda dengan lingkungan pembaca. ${ }^{21}$ Dengan demikian hermeneutik mengarahkan agar teks yang sedang dipelajari 
mempunyai arti sekarang dan di sini, sehingga teks tersebut mengarah secara terbuka menjadi yang sekarang dan di sini.

Dalam konteks agama, hermeneutik bertugas bagaimana menjelaskan isi sebuah teks keagamaan masyarakat yang hidup pada tempat dan kurun waktu yang jauh berbeda dari empunya, karena proses hermenutik adalah proses pemahaman, penafsiran dan penerjemahan sebuah pesan baik tertulis maupun ucapan yang selanjutnya disampaikan kepada masyarakat. Dalam studi keislaman, hermenutik sudah lama dikenal dan masuk dalam kajian tafsir dan lainnya. Padanan kata yang dianggap sebagai hermenutik adalah tafsir, ta'wil, syarah, dan bayan.

Jarak waktu, tempat dan suasana kultural antara pembaca dengan teks dan san pengarang (empunya) sudah barang tentu melahirkan keterasingan di satu sisi dan kesenjangan bahkan deviasi makna pada sisi yang lain, persoalan keterasingan inilah yang menjadi perhatian utama hermeneutika sebagai sebuah teori interpretasi, sehingga pemahaman teks dalam teori-teori hermeneutika mengharuskan pembedahan antara makna teks dengan perkembangan zaman. Dari situ dapat diketahui bahwa tuga pokok heremeneutik adalah bagaimana menafsirkan sebuah teks klasik atau teks asing sama sekali menjadi milik kita yang hidup di zaman, di tempat serta suasan kultural yang berbeda.

\section{b. Perkembangan Hermeneutika}

Pada awalnya hermeneutik banyak dipakai oleh mereka yang berhubungan erat dengan kitab suci Injil dalam menafsirkan kehendak Tuhan kepada manusia, karena pada awalnya hermeneutik ini hanya difahami sebagai metode untuk manasfsirkan teks-teks yang terdapat dalam kitab suci dan buku-buku klasik lainnya. ${ }^{22}$ Namun hermeneutik mulai berkembang pada abad ke-17 dan $18 \mathrm{M}$ dengan mulai dilakukannya untuk pendekatan disiplin ilmu yang lain tidak hanya kitab suci. ${ }^{23}$

Sedangkan kajian terhadap hermeneutik sebagai sebuah bidang keilmuan mulai marak pada ke-20, karena semakin maraknya kajian hermeneutika pada disiplin ilmu-ilmu, Palmer mengklasifikasikan cabang-cabang studi hermeneutik sebagai berikut: ${ }^{24}$

1. Interpretasi terhadap kitab suci, disebut exegesis

2. Interpretasi terhadap berbagai teks kesusastraan lama, disebut philology

3. Interpretasi terhadap penggunaan dan pengembangan aturanaturan bahasa, disebut technical hermeneutis

4. Studi tentang proses pemahamannya itu sendiri, disebut philosophical hermeneutics. 
5. Pemahaman dibalik makna-makna dari setiap simbol, disebut drean analysis

6. Interpretasi terhadap pribadi manusia beserta tindakan-tindakan sosialnya, disebut social hermeneutics.

Keenam perkembangan diatas tampak bahwa kajian hermeneutik berkembang pesat dan kini telah menampilkan bentuknya sebagai suatu kajian penting dalam memahami teks dan pemikiran lainnya, keenam pembagian hermeneutika itu juga merupakan fenomena hermeneutik kontemporer. Maka para cendekiawan sekarang mulai menggunakan hermeneutik untuk mendekati kajiannya masing-masing, karena diskursus hermeneutik semakin berkembang dan ia tidak hanya dalam kajiak kitab suci melainkan juga diplin ilmu yang lain, seperti teks keagamaan, sejarah, hukum, filsafat, alquran dan juga hadis.

\section{Biografi Yusuf Al-Qordhowi}

a. Riwayat dan Latar Belakang Pendidikannya

Nama lengkapnya adalah Yusuf al-Qordhowi ada yang menyebutnya Yusuf al-Qaradawi, lahir di desa kecil Republik Arab Mesir yang bernama Shaft Turab di tengah Delta sungai Nil tepatnya daerah Mahallah al-Kubro Propinsi alGharabiyah. Beliau lahir tanggal 9 September 1926 dari keluarga biasa yang berprofesi sebagai petani. Umur 2 tahun beliau ditinggal wafat ayahnya Abdullah, kemudian diasuh paman dan bibinya. Pamannya lah yang mengantarkan yang mengantarkan al-Qordhawi menjadi terpelajar. Beliau dianugrahi kecerdasan yang luar biasa, dengan kecerdasan itulah beliau mampu mengahafal alquran dan hukum tajwidnya diusia 10 tahun, diusian yang relatif muda itu pula masyarakat manejadikannya imam. ${ }^{25}$

Pendidikan formal beliau mulai dari sekolah di lembaga pendidikan alAzhar dan mendapatkan gelar al-'Allamah dari gurunya karena kecerdasan beliau yang luar biasa, setamat SD beliau melanjutkan ke ma'had Thanta selama 4 tahun, kemudian syahadah (ijazah) Aliyah beliau peroleh pada tahun 1952, tahun 1957 beliau melanjutkan studinya ke Ma'had al-Buhuts wa Dirasat alArabiyah al-Aliyah setingkat D3 dibidang bahasa arab dan sastra arab, pada saat yang sama beliau juga kuliah di fakultas Ushuluddin Universitas al-Azhar Kairo konsentrasi studi aqidah, filsafat, tafsir, dan hadis. Kuliah nya ini diselesaikan pada tahun 1960 dan menjadi satu-satunya mahasiswa yang lulus saat itu. Setamat studinya ini beliau mengikuti program doktoral di Universitas yang sama dengan judul disertasi " az-zakat wa atsaruhu fi hill al-Masyakil alIjtima'iyah" (zakat dan pengaruhnya dalam mengatasi problematika sosial) selesai tahun 1973 dengan predikat cumlaude. ${ }^{26}$ 
Secara formal pendidikan al-Qordhowi banyak menekuni pada bidang ushuludiin dan syariah, tetapi itu tidak menghalangi beliau untuk mempelajari ilmu keislaman yang lain seperti pusis, sastra, dan ilmu-ilmu yang lain, maka tidak heran jika al-Bauzi mengatakan bahwa al-Qordhowi adalah seorang cendekiawan muslim yang multi talenta dan memiliki pemeikiran jauh ke depan, hal itu terlihat dari banyaknya karangan yang sudah beliau hasilkan. ${ }^{27}$

\section{b. Pemikiran Yusuf al-Qordhowi}

Pemikiran al-Qordhawi banyak dipengaruhi dari bacaan yang beliau kagumi, diantaranya adalah buku tasawuf yang cenderung berkeagamaan klasik yaitu karya as-Sya'roni yang cenderung salafiah, kemudian karya-karya alGhozali yang lebih pada nuansa tasawuf sampai beliau bergabung dengan JI (jamaah ikhwan al-Muslim) yang dimotori Hasan al-Banna. ${ }^{28}$

Pada perkembangannya pemikiran al-Banna banyak mempengaruhi pemikiran al-Qordhowi, hal itu bisa dilihat dari sikap alQordhowi yang mengutamakan persatuan dan kesatuan ummat, menganggap bahwa perbedaan furu'iyah adalah suatu kemestian dan juga harus membebaskan dari fanatisme mazhab, larangan taqlid. ${ }^{29}$ Di sisi lain beliau juga terkenal moderat, beliau mengedepankan pada sumber primer yaitu alquran dan hadis tetapi beliau juga siap menerima pendapat dari manapun kalaupun itu bersandar pada yang benar.

Untuk memetakan pemikiran al-Qordhowi ada beberapa gagasan yang khas, yaitu:

1. Jalan Tengah

Jalan tengah adalah suatu sikap yang ada ditengah antara gampang dan ketat dalam mengambil hujjah dan penentuan hukum, alQordhowi selalu mengambil jalan moderasi dan tengah asalkan sesuai dengan maqashid alsyari'ah, bahkan beliau dinobatkan sebagai pioner moderasi di zaman modern. Hal itu beliau menyandarkan pendapatnya pada surat al-Baqarah ayat 143 :

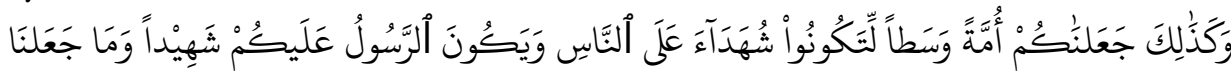

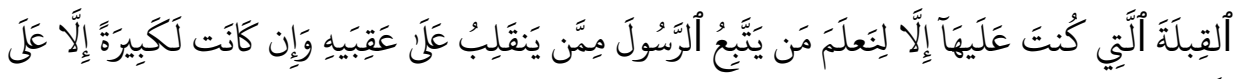

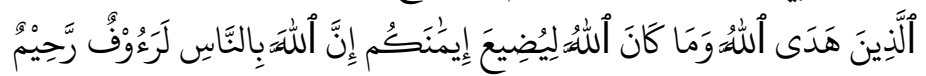

"dan demikian kami jadikan kamu (umat Islam) umat yang adil dan pilihan, agar kamu menjadi saksi atas (perbuatan) manusia dan agar Rasul (Muhammad) menjadi saksi atas perbuatan kamu" 


\section{Salafiah Moderat}

Salafiah adalah suatu aliran keagamaan yang berpendirian bahwa untuk mendirikan kejayaan umat Islam harus mengambil kembali ajaran yang masih murni seperti yang diamalkan generasi awal yaitu Nabi dan sahabat (salaf al-sholeh). ${ }^{30}$

Sedangkan yang disebut moderasi adalah sikap pertengahan antara dua kutub yang ekstrim yaitu liberal dan ekstrim. Dengan demikian al-Qordhowi memposisikan diri diantara dua jalan tersebut, beliau membahas cara orangorang ektrim dan tekstualis berpendapat dan juga membahas orang-orang liberal bependapat, kemudian beliau menentukan manhaj moderat untuk mendapatkan pemahaman agama yang lues.

Dengan pemetakan pemikiran tersebut dapat diketahui bahwa pemikiran beliau selalu melihat kondisi umat masyarakat, dengan patokan maqashid Ammah tanpa eksploitasi pemahaman atau adanya kepentingan pribadi maupun kelompok, al-Qordhowi selalu mendengungkan salah satu ungkapannya "sesungguhnya apa yang kami yakini dan yang kami serukan adalah sikap moderat bagi umat yang moderat". ${ }^{31}$

\section{Metode Yusuf Al-Qordhowi Dengan Tinjauan Hermeneutika}

a. Metode Yusuf al-Qordhowi dalam Memahami Hadis

Dalam pengambilan hadis sebagai dasar hukum, al-Qordhowi sangat hatihati dan menetukan aturan-aturan yang terkait sanad dan matan. Adapun prinsip dasar yang beliau pakai dalam beriteraksi dengan sunnah, yaitu pertama, Meneliti tentang keshahihan hadis tersebut sesuai dengan ketentuan ulama hadis. Kedua, Dapat memahami dengan benar nas-nas yang berasal dari Nabi yaitu sesuai dengan pengertian bahasa dan konteks hadis tersebut. ${ }^{32}$

Selain kedua hal itu al-Qordhowi juga menaruh perhatian besar dalam pemahaman hadis, besarnya perhatian beliau karena hadis memerlukan penelitian dua kali lebih ketat dibanding alquran, karena ada beberapa hal yang menjadikan hadis butuh pengkajian yang mendalam, yaitu: hadis hanya sebatas dhanny, tidak semua hadis ada penjelasannya, para ulama dalam memahami hadis pada umumnya cenderung memfokuskan proses periwayatan dengan menekankan pada kajian sanad.

Di sisi lain dalam upaya memahami hadis, pola fikir al-Qordhowi telah terkonstruksi sedemikian rupa, karena beliau selalu memperhatikan sisi internal da eksternla hadis. Segi internal hadis yaitu mengenai isnad, al-Qordhowi tidak memakai suatu hadis sebelum beliau tahu kualitas hadis tersebut secara pasti, tidak hanya mengandalkan kemasyhuran hadis semata. ${ }^{33}$ Sementara dari sisi 
eksternalnya adalah dari segi pemahaman hadis itu sendiri, atau ma'anil hadisnya.

Adapun cara al-Qordhowi dalam memahami hadis adalah dengan menerapkan beberapa prinsip yang sesuai dengan maqashid alSyari' ah, ${ }^{34}$ yaitu:

1. Memahami Sunnah Sesuai Petunjuk Alquran.

Menurut al-Qordhowi dalam memahami hadis harus terlebih dahulu melihat yang ada dalam alquran sehingga tidak bertentangan dengan petunjuk nya, sehingga hadis gharanik ${ }^{35}$ menurut al-Qordhowi tidak bisa diterima karena bertentangan dengan alquran walaupun sanadnya shahih. Tetapi sikap menjauhi hadis yang bertentangan dengan alquran harus melewati seleksi yang adil sehingga tidak mudah meninggalkan hadis yang hanya karena kelihatan bertentangan secara lahiriahnya saja.

Sebagai contoh hadis orang mati diazab karena tangisan keluarga nya seolah bertentangan dengan ayat alquran surat alAn'Am ayat 164, bunyi teks nya adalah:

Bunyi Hadis, ${ }^{36}$

$$
\begin{aligned}
& \text { عن عبد الله، أن حفصة بكت على عمر، فقال: مهل يا بنية ألم تعلي أن رسول الله صلى الله } \\
& \text { عليه وسلم، قال: (اإن الميت يعذب ببكاء أهله عليه }
\end{aligned}
$$

Bunyi Ayatnya

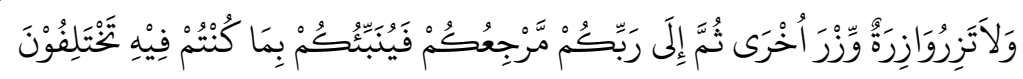

Melihat sepintas seolah dua dalil tersebut bertentangan, teks hadis tersebut menjelaskan bahwa orang yang meninggal kemudian keluarga yang ditinggaklan merapati bahkan sampai menangis maka mayat akan terkena siksa, sementara ayat tersebut menjelaskan bahwa sesorang tidak akan disiksa kareana perbuatan orang lain.

Dalam menghadapi dua teks tersebut al-Qordhowi melihat pendapat para ulama dalam kitab-kitab kemudian didapatkan bahwa Aiyah menceritakan bahwa yang kena siksa karena tangisan yang masih hidup adalah orang kafir.

2. Menghimpun hadis-hadis yang terjalin dalam tema yang sama.

Untuk memahami hadis secara sempurna menurut al-Qordhowi harus dihimpun semua dalam tema yang sama, sehingga bisa dilakukan untuk pemahaman mutasyabih dibawa ke muhkam, mutlak ke muqayyad, 'Am ke khas, karena memahami hadis hanya dari sisi lahiriahnya saja seringkali menjerumuskan pada pemahaman yang salah dan jauh dari konteks hadis. ${ }^{37}$ Contoh hadis tentang pemahaman larangan memakai sarung sampai bawah mata kaki: ${ }^{38}$ 


$$
\begin{aligned}
& \text { عن أبي ذر، عن النبي صلى الله عليه وسلم قال: الثلثة ل يكلمهم الله يوم القيامة، ول ينظر إليهم ول }
\end{aligned}
$$

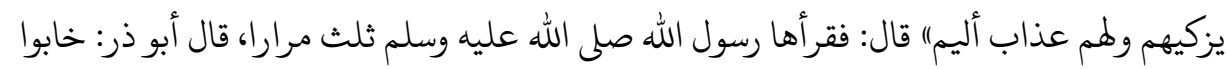

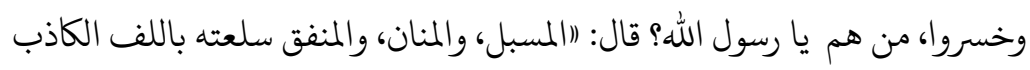
yaitu: ${ }^{39}$

Hadis ini difahami al-Qordhowi dengan melihat hadis yang sepadan

$$
\begin{aligned}
& \text { عن سا لم، عن أ بيه، أنّ رسو ل الله صلّ الله عليه و سلّم قال : من جرّ ثوبه من الخيلاء لا ينظر }
\end{aligned}
$$

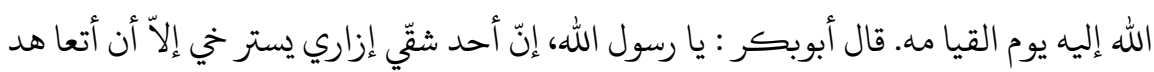

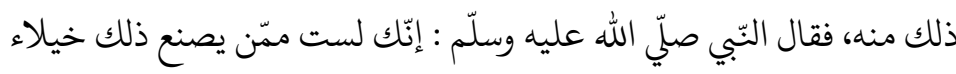

Dengan mengumpulkan hadis dalam tema yang sama maka bisa difahami bahwa pelarangan memakai sarung sampai mata bawah mata kaki adalah bagi mereka yang karena kesombongan.

3. Penggabungan atau pentarjihan antar hadis-hadis yang tampak bertentangan.

Dalam studi hadis sudah banyak dibahas tentang adanya hadis bertentangan dengan hadis lain, menurut para ulama hadis pemahaman hadis yang bertentangan boleh dilakukan jika hadis itu sama-sama bersanadkan shahih minimal hasan dan bukan dhoif apalagi maudhu, karena kalau maudhu' bisa langsung ditiggalkan. ${ }^{40}$

Al-Qordhowi mensikapi hadis yang bertentangan adalah pertama dengan menggabungkan antara kedua nash kemudian mentarjih diantara keduanya. ${ }^{41}$ Contoh tentang pelarangan $\mathrm{Nabi}$ untuk ziarah bagi perempuan:

Hadis Pertama: ${ }^{42}$

$$
\text { عن أبي هريرة رضي الله عنه ان رسول الله صلي الله عليه وسلم قال لعن الله زوارات القبور }
$$

Hadis kedua: ${ }^{43}$

$$
\begin{aligned}
& \text { عن سليمان بن بريدة، عن أبيه قال: قال رسول الله صلى الله عليه وسلم: (اقد كنت نهيتكم } \\
& \text { عن زيارة القبور، فقد أذن لمحمد في زيارة قب أمها، فزوروها فئن فإنها تذكر الآخرة }
\end{aligned}
$$

Melihat kedua hadis tersebut maka jelas ada pertentangan, hadis pertama melarang perempuan berziarah kubur sedangkan yang kedua meperbolehkan. Dalam memahami teks ini ulama mempunyai beberape adapat, menurut al-Qurtubi pelarangan itu diperuntukkan bagi perempuan yang terlalu sering melakukan ziarah kubur sehingga dia lupa akan kewajbina dirumah, kemudian mayoritas ulama memahaminya bahwa pelarangan itu hanya ada pada masa awal Islam sebelum kuat iman umat 
Islam terutama yang perempuan, kemudian Nabi memunculkan hadis yang kedua sebagai sebuah pembolehan. ${ }^{44}$ Demikian juga yang ditempuh alQordhowi dalam memahami hadis yang bertentangan.

4. Memahami hadis dengan mempertimbangkan latar belakang serta tujuannya.

Menurut al-Qordhowi Dalam konteks ini asbab al-Wurud sebagai pertimbangan penting ketika ingin memahami hadis, sehingga akan didapatkan pemahaman yang benar dan terhindar pelbagai perkiraan yang menyimpang dan terhindar dari pengertian yang jauh dari tujuan.

Pendekatan semacam ini disebut dengan pendekatan sosio-historis. Pendekatan historis menekankan pada kondisi sejarah ketika sebuah hadis dikeluarkan, termasuk didalamnya sosio kultural Nabi dan sahabat pada saat itu, sementara pendekatan sosiologis adalah menekankan pada penerimaan hadis tersebut.

Oleh karena itu menurut al-Qordhowi dalam memahami hadis dalam hal ini harus dilakukan beberapa hal, yaitu pemilahan antara yang bersifat khusus dan umum, yang sementara dan abadi, yang partikular dan universal.

Contoh pemahaman hadis tentang kepemimpinan perempuan: ${ }^{45}$

عن أبي بكرة قال: عصمني الله بشيء سمعته من رسول الله صلى الله عليه وسلم لما هلك كسرى، قال: "امن استخلفوا؟؟) قالوا: ابنته، فقال النبي صلى الله عليه وسلم: (الن يفلح قوم ولوا أمرهم امرأة Pengertian secara literalnya adalah bahwa tidak akan sukses suatu kaum jika menyerahkan urusan atau kepemimpinan kepada seorang perempuan. Pemahaman literal inilah yang sering digunakan ulama konservatif tentang tidak bolehnya perempuan menjadi pemimpin. ${ }^{46}$

Tetapi di sisi lain, menurut al-Qordhowi hadis ini perlu dicari tentang asbab wurud Nabi menyabdakan hal tersebut, diketahui bahwa hadis itu muncul ketika Nabi menyaksikan diangkatnya seorang perempuan yaitu Syairowaih ${ }^{47}$ menjadi ratu di Persia, padahal saat itu Persia dan arab pada khususnya sangat kental dengan tradisi ptrairkhi, perempuan adalah makhluk yang tidak mempunyai kewibawaan dan tempat di masyarakat, sehingga Nabi menyabdakan hadis tersebut adalah untuk menjaga kestabilan sebuah tatanan masyarakat, karena tidak mungkin sebuah bangasa dipimpin orang yang tidak mempunyai kewibawaan dan tempat. Jadi hadis tersebut hanyalah bersifat temporal bukan umum, sehingga hadis diatas tersebut harus difahami secara kontekstualnya bukan tekstualnya.

5. Membedakan antara sarana yang berubah-rubah dan sasaran yang tetap 
Maksudnya dari sarana adalah hadis zaman, pembicara, dan kondisinya, sedangkan sasarannya adalah tetap yaitu kemaslahatan umat. Setiap sarana dan pra sarana mungkin saja berubah tetapi itu hanyalah menjelaskan suatu fakta, namun sama sekali tidak dimaksudkan untuk mengikat dengannya.

Contoh hadis Nabi yang berkaitan dengan timbangan Makkah dan takaran Madinah, ${ }^{48}$

$$
\text { اهل المدينة عمر قال قال رسول الله صلي الله عليه وسلم الوزن وزن اهل مكة والمكيال مكيال }
$$

Hadis ini diucapkan Nabi untuk menghilangkan persengketaan di kalangan sahabat sehingga dibakukan menjadi timbangan makkah dan Madinah, tetapi pada perkembangannya tidak harus patokan pada timbangan Madinah melainkan disesuaikan dengan perkembangan zaman dan kondisi masyarakatnya masing-masing, karena hadis tersebut tidak bersidat ta'abudy yang tidak bisa diubah melainkan hal muamalah. ${ }^{49}$

6. Membedakan yang hakiki dan majazi

Hadis hakiki adalah hadis yang ungkapannya menggunkan lafal yang sebenranya, sedangkan majazi adalah hadis yang diungkapnkan tidak dengan bahasa asli melainkan bahasa simbolis harus ditafsirkan lagi.

Contoh hadis yang hakiki ${ }^{50}$

$$
\text { عن أبي هريرة رضي الله عنه، قال: اسمى النبي صلى الله عليه وسلم الرب خدعة }
$$

Dikatakan oleh Nabi bahwa adalah siasat, maka hadis itu harus difahami apa adanya bahwa perang pasti menggunakan siasat.

Contoh hadis majazi ${ }^{51}$

$$
\begin{aligned}
& \text { عن عائشة رضي الله عنها: أن بعض أزواج النبي صلى الله عليه وسلم، قلن للنبي صلى الله }
\end{aligned}
$$

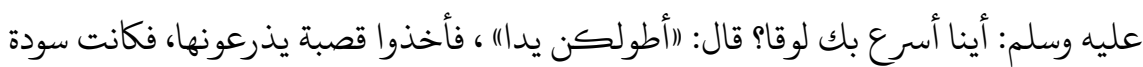

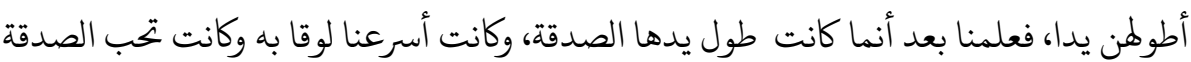

Hadis di atas mengungkapkan bahwa diantara istri Nabi yang paling cepat menyusul Nabi adalah yang paling panjang tangannya, panjang tangan tersebut adalah majaz, maka harus difahami dengan pemaknaan lain yaitu yang banyak sedekahnya.

\section{Tinjauan Hermeneutika terhadap Metode Pemahaman Hadis Yusuf al-Qordhowi}

Dalam memahami hadis pada era modern ini tidak cukup dengan menggunakan metode lama seperti tahlili atau tajzi'i tetapi ada juga ta'wil dan bayan, sehingga pemkanaan itu harus selalu melihat dan merespon 
perkembangan zaman sebagaimana pemahaman alQordhowi di atas. Ide-ide itu pada tatanan metode baru sama dengan istilah hermeneutika, sebagaimana upaya pencarian makna oleh filolog tradisional dan hermeneuen romantic ingin merekostruksi masa lalu ke dalam masa kekinian. ${ }^{52}$ Upaya pribumisasi hadis dan teks-teks keagamaan lain merupakan sesuatu yang diperlukan dan memahami teks sesuai dengan proporsinya, hal mirip kalau tidak sama dengan ide alQordhowi yaitu memahami hadis sesuai dengan maqashid alSyariah.

Dalam hermeneutika ada beberapa teori yang berkembang, diantaranya yang diprakarsai Friederich Schleimacer (1768-1834) dengan teori rekonstruksi historis, cara kerjanya adalah: pertama, makna harus sesuai dengan konteks masa itu dengan membahas awal mula sebuah pernyataan muncul kemudian mencari makna dari kenyataan itu. Kedua, merekonstruksi makna dengan memahami teks yang tertulis. Hermeneutika harus mampu memahami teks sebaik atau lebih baik dari pengarangnya dan memahami pengarang teks lebih baik dari pada memahami diri sendiri. ${ }^{53}$ Selain Schleimacer, ada wilhelm Dilthey (1833-1911) menurutnya hermeneneutika adalah mencari pemahaman yang sesuai dengan masa, karena makna itu sendiri tidak pernah berhenti pada satu masa melainkan seperti benda cair dan tidak pernah ada hukum untuk interpretasi. $^{54}$

Melihat teori yang dimunculkan oleh para tokoh, penulis berasumsi bahwa ada kesamaan teori hermeneutika dengan teori alQordhowi dalam memahami hadis:

Pertama, makna harus sesuai dengan konteks masa dengan merekonstruksi makna. Dalam hal ini al-Qordhowi memakai istilah asbab al-wurud hadis, sehingga menemukan yang benar.

Kedua, memahami teks tidak cukup dengan menggunakan gramatika bahasa, melainkan harus memahami yang tersembunyi dari bahasa itu, alQordhowi juga menekankan pemahaman hadis tidak hanya teksnya saja melainkan juga aspek yang lain. Ketiga, mehamai teks tidak harus statis, dalam hal ini al-Qordhowi menekankan pehamahaman hadis harus sesuai dengan perkembangan zaman dan konteks yang ada. Keempat, tugas hermeneutika adalah mencari makna yang baik atau lebih baik. Dalam hal ini al-Qordhowi memakai istilah dengan mencari makna yang sesuai dengan maqashid alsyariah.

Upaya pemahaman hadis dengan memakai metode hermeneutika adalah sebuah upaya untuk memahami hadis secara kontekstual, dengan demikian hadis tidak hanya bisa dipakai pada zaman disabdakan tetapi bisa digunakan untuk kepentingan masyarakat dean sebagai hujjah. Tetapi dalam 
perkembangan pemahaman hadis menurut sebagian ulama adalah yang cocok adalah dengan cara tematik, karena hadis akan dikupas dan dikumpulkan secara menyeluruh, sehingga akan diketahui adakah pertentangan hadis, hakiki majazinya, penafsiran dengan hadis serupa, dan lain lain.

Dalam memahami hadis yang nota benenya adalah pengejawantahan qoul, fi'il, dan taqrir Nabi yang muncul berabad abad silam maka ada tiga rangkai yang tidak bisa terpisah yaitu teks hadis, pengarang, dan pembaca, unsur ketiga adalah para pengkaji hadis termasuk kita saat ini.

Ulama mutaqodimin sudah banyak melakukan pensyarahan terhadap hadis, tetapi masih terlalu banyak yang belum dijelaskan bahkan waktunya sudah banyak terjadi perekembangan dan perubahan peradaban, ulama mutaakhirin lebih banyak memperbaharui metode mutaqadimin, oleh karenanya pikiran-pikiran yang telah ada harus ditindaklanjuti agar mengahsilkan pemahaman yang tepat dan menyeluruh.

Dengan melihat metode baru yang bisa diterapkan maka kita bisa mengapresiasi usaha mereka termasuk al-Qordhowi, tetapi dalam sebuah teori tidak bisa dihindarkan dari adanya kekurangan termasuk al-Qordhowi.

\section{Simpulan}

Berdasarkan kajian dan pembahasan yang telah dipaparkan, maka dapat diambil beberapa kesimpulan sebagai berikut:

1. Dalam pandangan Yusuf al-Qordhowi, hadis nabi merupakan petunjuk dari serangkaian peraturan-peraturan yang telah ditetapkan secara pasti, alQordhowi juga menegaskan bahwa kebutuhan kaum muslimin dewasa ini adalah melakukan pengujian kembali terhadap berbagai bentuk hadis sesuai dengan kondisi zaman. Hal itu bisa dilakukan dengan menerapkan beberapa metode yang telah ditawarkan Qordhowi dengan tidak menyepelehkan aturan-aturan yang sudah ditetapkan para muhadditsin. Tawaran al-qordhowi tersebut adalah:
a. Memahami Hadis sesuai petunjuk alquran
b. Menghimpun hadis-hadis yang terjalin dalam tema yang sama
c. Menggabungkan atau mentarjih antar hadis yang tampaknya bertentangan
d. Memahami hadis dengan mempertimbangkan latar belakang serta tujuannya
e. Membedakan antara sarana yang berubah-ubah dan sasaran yang tetap
f. Membedakan yang hakiki dan majazi 
2. Implikasi penafsiran dan pemahaman hadis dengan pendekatan yang beraneka ragam yang ditawarkan Qordhowi ada kemiripan sangat jelas dengan metode hermeneutika, hal itu dapat dilihat dari cara kerja dan konsep hermeneutika yaitu memahami teks sesuai dengan kebutuhan manusia yang makin berkembang dengan melihat beberapa aspek. Dengan demikian hadis bisa hadis dijadikan sebagai jawaban dari wacana baru, dinamis dan kreatif sehingga norma dan ideal sunnah Nabi dapat direalisasikan secara progresif di dalam aneka ragam fenomena dan lingkungan sosial, karena ia senantiasa dapat mencari bentuk yang baru dan segar bagi realisasi dirinya. Kaitannya dengan kedudukan hadis sebagai sumber hukum yang otoritatif, maka dengan pendekatan yang seperti itu, hadis akan menjadi 'pintu gerbang' bagi perumusan struktur hukum Islam yang dinamis dan kreatif dalam rangka memenuhi kebutuhan masyarakat yang senantiasa berubah secara progresif. Hadis tidak menjadi kendala bagi penciptaan cita-cita nuansa hukum modern.

3. Penggunaan teori hermeneutika dalam studi hadis sebenarnya memiliki akar-akar historis yang kuat dalam khazanah pemikiran islam, seperti adanya asbab al-wurud adalah merupakan salah satu bukti yang tidak terelakkan, selain itu juga adanya penekanan bahwa pemahaman tidak cukup dengan gramatika bahasa saja tetapi menemukan makna yang lebih baik adalah sesuai dengan dalam bahasa Qordhowi 'maqashid as-syariah. Sehingga dengan asumsi demikian, maka gagasan yang bernuansa hermeneutika hadis yang ditawarkan Qordhowi secara substansila bukanlah sesuatu yang baru, hanya saja Qordhowi memakai bahasa kesesuaian dengan maqashid syariah dengan berpatokan pada aturan para muhadditsin.

Berdasarkan dari temuan-temuan penelitian, maka dapat diajukan beberapa saran sebagai berikut:

Pertama, perumusan metodologi penafsiran dan pemahaman hadis masih merupakan wilayah kajian yang sangat mendesak. Mengingat kajian-kajian metodologi tafsir lebih banyak ditujukan pada alquran. Kedua, berkembangnya metodologi tafsir dalam tradisi keilmuan barat yang populer dengan metode hermeneutika menunjukkan nuansa lain, jika dibandingkan dengan metodologi yang ada dalam hadi masih jauh tertinggal, oleh karena itu para pengkaji keislaman harus lebih membuka peluang besar terhadap metodologi pemahaman hadis termasuk dengan memakai hermeneutika. 


\section{Daftar Pustaka}

Abdullah, M.Amin, Studi Agama Normatifitas dan Historisitas, cet. Ke1, (Yogyakarta: Pustaka Pelajar, 1996)

Abu al-Falah, Syarh al-Zahab fi Akhbar man Zahab, (t.tp: Dar al-Fikr, 1979)

al-Albani, Nasihruddin, Sunan an-Nasa'i, (Beirut: Dar al-Fikr, t.t)

al-Asqolani, Ibnu Hajar, Fathul Bari, Jld. 8 dan 3, (Ttp: al-Maktabah alKulliyah al-Azhariyah, 1398/1978)

al-Bukhori, Muhammad bin Ismail, Shahih Bukhori, Jld. II, (Dar alFikr, $1415 / 1995)$

al-Ghozali, Muhammad, as-Sunnah an-Nabawiyah Baina Abli Fiqh wa Abli alhadis, Cet.ke-4, (Kairo: Dar al-Syuruq, 1998)

Ali Bauzi, Abd Rahman (ed.), Rangkuman Biodata Yusuf al-Qordhawi: Fatwa alQordhowi, permasalahannya, Pemecahan dan Hikmah, (Surabaya: Risalah Gusti, 1994)

al-jauhari, Imam Hanafi, Hermeneutika Islam: Membangun Peradaban Tuhan di Pentas Global, (Yogyakarta: Ittiqa Press, 1999)

al-Qordhawi, Yusuf, Syaikh Muhammad al-Ghozali yang saya kenal: setengah abad Perjalanan Pemikiran dan Gerakan Islam, ter. (Jakarta: Rabbani Press, 1997) , al-Ijtihad al-Mu'asir, (Kairo: Dar al-Tauzi' wa an-Nashr alIslamiyah,t.t) , Hukum Zakat, terj. Salman Harun, et.al., cet.ke-3, (Jakarta: Pustaka Litera Antar Nusa, 1993)

, Kaifa Nata'amal Ma'a as-Sunnah an-Nabawiyah, (USA, Virginia: Ma'had al-Islami, 1990)

Terj. Moh. Baqir, Bagaimana Memahami Hadis Nabi, (Bandung: Karima,1999) , Kaifa Nata'amal Ma'a as-Sunnah Nabawiyah, (USA: Virginia al-Ma'had al-Islami, 1990)

, Kajian Kritik Pemahaman Hadis: Antara Pemahaman Tekstual dan Kontekstual, terj. A. Najuyullah dan Hidayatullah, (Jakarta: Islamuna Press, 1991)

al-Qusyairi, Muslim bin Hajjaj, Shahih Muslim, (Beirut: Dar al-Fikr, 1993)

as-San'ani, Ismail, Subulus Salam: Syarh Bulughul Maram, (Mesir: Mustofa alBabi al-Halabi wa Auladuhu, 1960)

as-shalih, Subhi, Membahas Ilmu-ilmu Hadis, (Jakarta: Pustaka Firdaus,2000)

as-Siddiqy, M. Hasbi, Pengantar Hukum Islam, (Semarang: Pustaka Rizki Putra, 1997)

as-Suyuthi, Jalal ad-din, Jami' as-Shoghir Fi Ahadits Basyir an-Nadzir, (Beirut: Dar al-Fikr, 1981) 
Bizawi, Zainul Milal, Perlawanan Kultural Agama Rakyat: Pemikiran dan Paham Keagamaan Syekh Mutamakkin dalam Pergumulan Islam dan Tradisi, Cet. Ke-1, (Yogyakarta: SAMHA, 2002)

C. Verhak dan R. Haryono, Filsafat Ilmu Pengetahuan: Telaah atas Kerjallmu-ilmu, Cet. Ke-2, (Jakarta: Gramedia Pustaka Utama, 1991)

E.Sumaryono, Hermeneutika: Sebuah Metode Filsafat, Cet. Ke-1, (Yogyakarta: Kanisius, 1998)

Hidayat, Komaruddin, Memahami Bahasa Agama: Sebuah Kajian Hermeneutik, Cet.ke-1, (Jakarta: Paramadinah, 1996)

Iqbal, Muhammad, The Reconstruction of Religious Thought in Islam (New Delhi: Kitab Bhavan, 1981)

K. Bertens, Filsafat Barat abad XX Inggris dan Jerman, Cet. Ke-1,(Jakarta: Gramedia, 1983)

Musahadi, Hermeneutika Hadis-hadis Hukum: Studi tentang Gagasan Fazlur Rohman, Penelitian, (Semarang:t.d) Nashr, Sayyid Hossen, Knoweldge and Secred, (State University Press, 1989)

Qutaibah, Muslim bin, Ta'wil Mukhtalaf al-Hadis, (Mesir: Maktabah Kulliyah al-Azhariyah, 1996),

Rahman, Fazlur, Wacana Studi Hadis Kontemporer, (Yogyakarta: Tiara Wacana).

Sunanto, T.H. Hasan, Hermeneutika: Prinsip dan Metode Penafsiran alKitab, Cet. Ke-5, (Malang: Seminari al-Kitab Asia Tenggara, 1993)

Suryadilaga, AlFatih, Metode Hermeneutika dalam Pensyarahan Hadis: Ke arah Pemahaman yang Ideal dan Komprehensip, Jurnal Studi Ilmu-ilmu al-Quran dan hadis, Vol. I, No.2, Januari 2001,195

Syadzali, Munawir, Islam dan Tata Negara: Ajaran dan Sejarah Pemikiran, (Jakarta: UI Press, 1990)

Talimah, Isham, Manhaj Fiqih Yusuf al-Qardhawi, Cet. Ke-1, terj. Samson Rahman, (Jakarta: Pustaka Kausar, 2001)

Tirmidzi, Sunan at-Tirmidzi, (Beirut: Dar al-Fikr, 1994)

W. Poespoprodjo, Interpretasi: Beberapa Catatan Pendekatan Filsafat, Cet. Ke1, (Bandung: Karya Remaja, 1987)

Yunahar Ali dan Mas'udi (ed.), Pengembangan Pemikiran Terhadap Hadis, cet. Ke.1, (Yogyakarta: LPPI, 1996).

\section{Endnotes}

1 Fazlur Rahman, Wacana Studi Hadis Kontemporer, (Yogyakarta: Tiara Wacana).ix 
2 Apa yang dilakukan atas ayat-ayat alquran oleh ulama merupakan suatu khazanah yang berarti bagi perkembangan ilmu-ilmu alquran saat ini. Kenyataan ini berbeda dengan tradisi hadis. Kebanyakan ulama hadis masih sering disibukkan dengan kajian intern teks, yaitu persoalan shohih tidaknya hadis dan penulusuran kredibilitas rowinya.

3 Dalam persoalan kehujjahan hukum hadis hanya sampai pada tataran dhanny, hal itu dikarenakan karena hadis adalah ucapan Nabi Muhammad sendiri berdasarkan wahyu dan tertulisnya memakan rentang waktu yang lama, sehingga mempunyai ranngkaian orang itu sambung sampai Nabi, sehingga penelusuran atas kredibilitas pembawa hadis itu memerlukan penelusuran agar tidak terjatuh pada sebuah berita palsu (hadis maudhu)

4 Dalam pensyaratan hadis shahih ulama menyepakati harus memenuhi syarat, yaitu: Pertama, harus bersambung sanadnya, kedua, diriwayatkan orang adil, ketiga, rawinya bersifat dhobit, keempat, tidak terdapat kejanggalan atau syadz dan kelima, tidak terdapat cacat atau 'ilat, lihat Hammam bin Abdurrahim Sa'id, al-Fikr al-Manhaji 'inda alMuhadditsin, (Qatar : Ri'asat al-Mahakim al-Syar' iyyat wa al-Syuun al-Diniyyat, 1998), h. 57. Muhammad Jalaluddin al-Qasimi, Qawa'id al-Tahdits , (Beirut : Dar al-Naghatis, 1984), 103

5 Musahadi, Hermeneutika Hadis-Hadis Hukum; Studi tentang Gagasan Fazlur Rahman, Penelitian (Semarang: t.td), 2-3.

6 Muhammad Iqbal, The Reconstruction of Religious Thought in Islam (New Delhi: Kitab Bhavan, 1981), 50

7 Yusuf Qordhowi, Kaifa Nata'amal Ma'a as-Sunnah an-Nabawiyah, (Virginia: al-Ma'had alAlami Li al-Fikr al-Islami, 1990) Cet. I. Terj. Moh. Baqir, Bagaimana Memahami Hadis Nabi, (Bandung: Karima,1999), 179

8 Hadits merupakan istilah yang biasa digunakan para pakar hadits dalam menyebut sesuatu yang berasal dari Nabi Muhammad saw, baik itu berupa perkataan, perbuatan atau ketetapan. Hadits berfungsi menjelaskan, memperkuat dan menyebutkan hukum yang terdapat dalam Alqur'an. Oleh karena itu hadits menempati peringkat kedua dalam hirarki sumber hukum Islam. Lihat Yusuf Qardhawi, Bagaimana Memahami Hadits Nabi ,. Terj. M. Bagir, Jakarta , 1993, h. 17

9 Yunahar Ali dan Mas'udi (ed.), Pengembangan Pemikiran Terhadap Hadis, cet. Ke.1, (Yogyakarta: LPPI, 1996), 57

10 M.Amin Abdullah, Studi Agama Normatifitas dan Historisitas, cet. Ke-1, (Yogyakarta: Pustaka Pelajar, 1996), 315

11 Muhammad bin Ismail al-Bukhori, Shahih Bukhori, Jld. II, (Dar al-Fikr, 1415/1995).109 dan Muslim bin Hajjaj al-Qusyairi, Shahih Muslim, Jld. I, (Beirut: Dar al-Fikr, 1414/1993), 206

12 Muhammad al-Ghozali, as-Sunnah an-Nabawiyah Baina Ahli Fiqh wa Ahli al-hadis, Cet.ke4, (Kairo: Dar al-Syuruq, 1998), 8-9 dan Ibnu Hajar al-Asqolani, Fathul Bari, Jld. 8 dan 3, (Ttp: al-Maktabah al-Kulliyah alAzhariyah, 1398/1978), 169-171

13 Hadis Taqririyah

14 Yusuf al-Qordhowi, Kaifa Nata'amal Ma'a as-Sunnah an-Nabawiyah, (USA, Virginia: Ma'had al-Islami, 1990), 138

15 E.Sumaryono, Hermeneutika: Sebuah Metode Filsafat, Cet. Ke-1, (Yogyakarta: Kanisius, 1998), 23 
16 Hermes ini digambarkan sebagai seseorang yang mempunyai kaki bersayap dan lebih dikenal dengan sebutan Mercerius dalam bahas latin. Ibid

17 Komaruddin Hidayat, Memahami Bahasa Agama: Sebuah Kajian Hermeneutik, Cet.ke-1, (Jakarta: Paramadinah, 1996), 13 dan W. Poespoprodjo, Interpretasi: Beberapa Catatan Pendekatan Filsafat, Cet. Ke-1, (Bandung: Karya Remaja, 1987), 91

18 Musahadi, Hermeneutika Hadis-hadis Hukum: Studi tentang Gagasan Fazlur Rohman, Penelitian, (Semarang:t.d), 89 dan Sayyid Hossen Nashr, Knoweldge and Secred, (State University Press, 1989), 71

19 AlFatih Suryadilaga, Metode Hermeneutika dalam Pensyarahan Hadis: Ke arah Pemahaman yang Ideal dan Komprehensip, Jurnal Studi Ilmu-ilmu al-Quran dan hadis, Vol. I, No.2, Januari 2001,195

20 Suatu istilah lain yang dekat dengan heremeneutik adalah exegesi atau penafsiran. Meskipun terdapat sinonimitas antara hermenutika dengan exegesis, tetapi pada hakekatnya terdapat nuansa yang berbeda, yakni pertama menunjuk pada teori dan metodologi penafsiran, sedangkan yang kedua pada aspek praksisnya. T.H. Hasan Sunanto, Hermeneutika: Prinsip dan Metode Penafsiran al-Kitab, Cet. Ke5, (Malang: Seminari al-Kitab Asia Tenggara, 1993), 3

21 C. Verhak dan R. Haryono, Filsafat Ilmu Pengetahuan: Telaah atas Kerja Ilmuilmu, Cet. Ke-2, (Jakarta: Gramedia Pustaka Utama, 1991), 175

22 Zainul Milal Bizawi, Perlawanan Kultural Agama Rakyat: Pemikiran dan Paham Keagamaan Syekh Mutamakkin dalam Pergumulan Islam dan Tradisi, Cet. Ke-1, (Yogyakarta: SAMHA, 2002), 5

23 K. Bertens, Filsafat Barat abad XX Inggris dan Jerman, Cet. Ke-1, (Jakarta: Gramedia, 1983), 224

24 Ibid, 6

25 Isham Talimah, Manhaj Fiqih Yusuf al-Qardhawi, Cet. Ke-1, terj. Samson Rahman, (Jakarta: Pustaka Kausar, 2001),3 dan Abd Rahman Ali Bauzi, (ed.), Rangkuman Biodata Yusuf al-Qordhawi: Fatwa al-Qordhowi, permasalahannya, Pemecahan dan Hikmah, (Surabaya: Risalah Gusti, 1994),399

26 Ibid.

27 Ibid, 400 dan Yusuf al-Qordhawi, Syaikh Muhammad al-Ghozali yang saya kenal: setengah abad Perjalanan Pemikiran dan Gerakan Islam, ter. (Jakarta: Rabbani Press, 1997),8

28 Hasan al-Banna terkenal sebagai seorang tokoh revolusioner muslim sekaligus spiritualis. Ibid, 221

29 Yusuf al-Qordhowi, Hukum Zakat, terj. Salman Harun, et.al., cet.ke-3, (Jakarta: Pustaka Litera Antar Nusa, 1993), 17

30 Munawir Syadzali, Islam dan Tata Negara: Ajaran dan Sejarah Pemikiran, (Jakarta: UI Press, 1990), 124

31 Yusuf al-Qordhowi, al-Ijtihad al-Mu'asir, (Kairo: Dar al-Tauzi' wa an-Nashr alIslamiyah,t.t), 4

32 Ibid

33 Mengenai syarat yang ditentukan al-Qordhowi dalam hal sanad hadis bisa lihat selengkapnya di buku beliau yaitu Kajian Kritik Pemahaman Hadis: Antara Pemahaman Tekstual dan Kontekstual, terj. A. Najuyullah dan Hidayatullah, (Jakarta: Islamuna Press, 1991), 97-101 
34 Maqashid as-syariah adalah tujuan syariat secara umum, diantara tujuan itu adalah: 1)Menciptakan dan menjaga kemaslahatan manusia, baik itu berhubungan dengan agama, jiwa, akal, keturunan maupun harta, 2) menyempurnakan segala yang diperlukan manusia untuk memudahkan dan untuk dapat menanggung kesukaran dan pembebanan (taklif), M. Hasbi asSiddiqy, Pengantar Hukum Islam, (Semarang: Pustaka Rizki Putra, 1997), 345

35 Hadis gharanik adalah sebuha hadis palsu karena menambahkan dalam teks hadis yang tidak termasuk teks asli, contoh penambahan teks dalam surat annajm padahal sanadnya shahih. Lihat Yusuf al-Qordhowi, Kaifa Nata'amal Ma'a as-Sunnah Nabawiyah, (USA: Virginia alMa'had al-Islami, 1990),97

36 Muslim bin Hajjaj al-Qusyairi, Shahih Muslim, (Beirut: Dar al-Fikr, 1993), bab Mayit yu'azabu bi bukai ahlihi, Jilid II, 638

37 Yusuf al-Qordhowi, Ibid., 113

38 Muslim, Shahih Muslim,Ibid, Juz I, 102

39 Nasihruddin al-Albani, Sunan an-Nasa'i, (Beirut: Dar al-Fikr, t.t), Juz 8, 208

40 Subhi as-shalih, Membahas Ilmu-ilmu Hadis, (Jakarta: Pustaka Firdaus,2000), 149

41 Yusuf al-Qordhowi, Ibid.,

42 Jalal ad-din as-Suyuthi, Jami' as-Shoghir Fi Ahadits Basyir an-Nadzir, (Beirut: Dar al-Fikr, 1981), 409

43 Tirmidzi, Sunan at-Tirmidzi, (Beirut: Dar al-Fikr, 1994), J. 3, 361

44 Muslim bin Qutaibah, Ta'wil Mukhtalaf al-Hadis, (Mesir: Maktabah Kulliyah al-Azhariyah, 1996), 89-90

45 Sunan Tirmidzi, J. 6, h.8

46 Ismail as-San'ani, Subulus Salam: Syarh Bulughul Maram, (Mesir: Mustofa alBabi al-Halabi wa Auladuhu, 1960),123

47 Syairawaih diangkat menjadi ratu setelah saudara laki-lakinya terbunuh, jatuhnya Persia adalah akibat dari sikap kakek dari Syairawaih yaitu Kisrah yang pernah menyobek surat Nabi ketika diajak bergabung untuk memeluk Islam, maka Nabi pada saat itu menyabdakan barang siapa yang menyobeknyobek suratku maka tidak akan lama Allah akan menyobek kekuasaanya, Lihat Abu al-Falah, Syarh al-Zahab fi Akhbar man Zahab, (t.tp: Dar alFikr, 1979), 13

48 Yusuf al-Qordhowi, Kaifa. Ibid, 149

49 Yusuf 1-Qordhowi, Ibid. 154

50 Bukhori, Shahih Bukhori, J. 4, h. 64

51 Ibid.,j.2, h. 110

52 Ada tiga ciri utama yang menjadi identitas hermeneutic romantisis: pertama, mencari makna asli pengarang yang terkandung dalam sebuah teks, kedua, penafsir harus mengesampingkan sejauh mungkin aspek-aspek subjektifitasnya, ketiga, jarak waktu yang membentang antara masa kini dan masa lalu harus dilampaui penafsir. Agus Darmaji, Hermeneutik: Sebuah Pengantar, makalah, 9-10

53 Imam Hanafi al-jauhari, Hermeneutika Islam: Membangun Peradaban Tuhan di Pentas Global, (Yogyakarta: Ittiqa Press, 1999), 31-32 54 Imam Hanafi, Ibid, 33

54 Imam Hanafi, Ibid, 33. 